Version of record: Krista A. Murchison. "A Presumed Lost Leaf of Lydgate's Testament." Notes and Queries. 65.2 (2018): 177-179.

Available here: https://doi.org/10.1093/notesj/gjy003

\title{
A PRESUMED LOST LEAF OF LYDGATE'S TESTAMENT
}

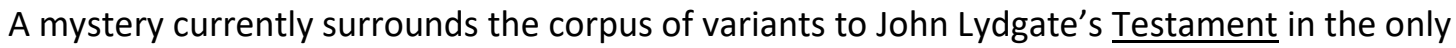
available critical edition of the poem - the 1911 edition produced by Henry Noble MacCracken.

Although MacCracken's edition includes variants for the last four stanzas of the poem taken from Leiden University Library, Vossius Germ. Gall. Q. 9 (more commonly known as the 'Leiden Lydgate manuscript'), these stanzas are in fact missing from that copy of the poem. ${ }^{1}$ This perplexing discrepancy was first noticed by J. A. Van Dorsten in his article on the Leiden Lydgate manuscript. ${ }^{2}$

One might suspect that the missing stanzas, which would have been on a single leaf, had been part of the manuscript when MacCracken was working on the edition in 1907-1908, then were misplaced at some later time and before Van Dorsten described the manuscript in 1960 . The brittle state of the few last leaves of the manuscript suggests that losses in this part might easily have occurred. But this explanation is ultimately untenable, since the manuscript contains the exact same number of leaves now as it did when F. N. Robinson described it in $1896 .^{3}$

The mysterious readings are better explained as editorial inventions. I came to this conclusion when checking all the variant readings that MacCracken claims to have taken from the Leiden

\footnotetext{
${ }^{1}$ John Lydgate, 'The Testament of Dan John Lydgate', The Minor Poems of John Lydgate, ed. Henry Noble MacCracken (Oxford, 1911), I, EETS e.s. 107, 329-36. MacCracken gives Leiden variant readings for II. 871, 880, 882, and 893. MacCracken's edition is the most commonly cited edition of Lydgate's Testament, as it is the only available critical one; the only other critical edition is an unpublished 1914 doctoral thesis: Hans Beutner's, 'Lydgate's Testament: Textkritische Ausgabe' (Munich University, 1914).

2 J. A. Van Dorsten, 'The Leyden "Lydgate Manuscript"', Scriptorium, 14.2 (1960), 319.

${ }^{3}$ F. N. Robinson notes that there are 270 pages (so 135 folios) in 'On Two Manuscripts of Lydgate's Guy of Warwick', Harvard Studies and Notes in Philology, 5 (1897), 186-187. The same number of pages is recorded by Van Dorsten, who states that the 'oldest Leiden catalogues never indicate more' than this number ('Leyden', 319).
} 
manuscript against the manuscript itself (the last four stanzas excepted for obvious reasons). ${ }^{4}$ Of the 53 Leiden variant readings recorded in the edition-places where MacCracken claims the Leiden manuscript differs significantly in spelling or wording from his base text-14 contain errors; in other words, over a quarter of the Leiden variants are wrong. ${ }^{5}$ It notable that errors are particularly common among the variant readings taken from the end of the manuscript-those that fall immediately before the four 'missing' stanzas.

This evidence confirms doubts about the authenticity of the Leiden variants that were supposedly recorded from the last four stanzas. The mistakes might suggest that MacCracken had no familiarity at all with the Leiden manuscript, but this explanation can probably be ruled out since some of the variants he records are indeed unique to this manuscript. These correct variants likewise rule out the possibility that MacCracken accidentally attributed an entire set of variants from another Lydgate manuscript to the Leiden one. Nevertheless, the large number of errors among the Leiden variants suggests that MacCracken was working from an imperfect transcription or from incomplete notes and may suggest that he had limited knowledge of the Leiden manuscript.

Aside from these mistakes, there are other indications that MacCracken was working from fragmentary material when he recorded variants from the Leiden manuscript. In his description of the fifteen manuscripts consulted, MacCracken gives the folio range for all manuscripts except the Leiden one. ${ }^{6}$ MacCracken, who was based in America at the time, notes in his preface that he performed primary research for the edition in England between 1907 and 1908, but there is nothing to suggest that

\footnotetext{
${ }^{4}$ I am grateful to the librarians of Leiden University Library for granting access to the manuscript.

${ }^{5}$ Errors in variant readings (places where, according to MacCracken, the Leiden manuscript differs in spelling or wording from his base text) are 'pote' (I. 9) for MS 'sote' (fol. 117r), 'knewe' (I. 32) for MS 'kne' (fol. 117v), 'roode' (I. 190) for MS 'rode' (fol. 120v), 'monthez' (I. 329) for MS 'monthes' (fol. 124r), 'corage' (I. 348) for MS 'visage' (fol. 124v), 'and' (I. 356) for MS 'now' (fol. 125r), 'enclyne' (I. 370) for MS 'declyne' (fol. 125r), 'and' (I. 470) erroneously described as omitted (fol. 127r), 'eche' (I. 597) for MS 'which' (fol. 129v), 'kowde' (I. 645) for MS 'koude' (fol. 130v), 'ofte' (I. 676) for MS 'often' (fol. 131v), 'observauntes' (I. 688) for MS 'observaunces' (fol. 131v), 'was nat but a' (I. 697) for MS 'was nat but' (fol. 132r), and 'the' (I. 746) for MS 'thy' (fol. 133r).

${ }^{6}$ MacCracken states only that the Testament appears in the 'last part of book, separately bound'; Minor Poems, 329. The leaves containing the Testament were indeed once separately bound; see Van Dorsten, 'Leyden', 316.
} 
he crossed the North Sea to consult Leiden's collections firsthand. He freely admits, moreover, to relying on 'copies of certain texts'. ${ }^{7}$ MacCracken promises a more complete description of all consulted manuscripts for the second volume, but this list is conspicuously absent from this volume. ${ }^{8}$

The lost Lydgate leaf is therefore a fiction created through editorial inaccuracy-one that points to the value of modern manuscript digitization and institutional support for primary research. ${ }^{9}$ It also underlines the growing and well-documented need for a new and corrected critical edition of Lydgate's Testament. ${ }^{10}$

K. A. MURCHISON
Leiden University
k.a.murchison@hum.leidenuniv.nl

\footnotetext{
7 Henry Noble MacCracken, 'Preface', The Minor Poems of John Lydgate, ed. Henry Noble MacCracken (Oxford, 1911), I, EETS e.s. 107, iv.

8 'Preface', iv; The Minor Poems of John Lydgate, ed. Henry Noble MacCracken (Oxford, 1934), II, EETS o.s. 192. ${ }^{9}$ Thanks to generous funding from Leiden University's Faculty of the Humanities, the manuscript is now available online in IIIF format here: https://digitalscholarship.nl/view/

${ }^{10}$ See, for example, Mary Wellesley, 'A Previously Unrecorded Manuscript Version of Lydgate's Testament', Notes and Queries 62.1 (2015), 27-28.
} 